\title{
THE INFLUENCE OF THE MACROECONOMICAL VARIABLES ON THE BANKRUPTCY RATE OF THE ROMANIAN ENTITIES WORKING IN THE AGRICULTURAL SECTOR
}

\section{Rodean (Cozma) Maria-Daciana Ph.D. student}

Faculty of Economics, Financial Department, "Lucian Blaga" University, Sibiu, Romania, maria.daciana89@yahoo.com

\section{Baltes Nicolae Ph.D.}

Faculty of Economics, Financial Department, "Lucian Blaga" University, Sibiu, Romania, baltes_n@yahoo.com

(Received November 2015; Accepted February 2016)

\begin{abstract}
The study's main objective is represented by the analysis of the reasons that lead to the appearance of an agricultural companies' default risk, based on the failure rate model developed by Wilson. In the construction of the regression model were taken into consideration the evolution of the two macroeconomic variables: the inflation rate and the variation of the exchange rate over a period of 4 years (2010-2013). The research' results have shown that the variation of the bankruptcy rate registered by the agricultural sector is 99.99\% explained by the variation of both of the macroeconomic explanatory variables.
\end{abstract}

Keywords: multiliniar regression, inflation rate, default rate, rate of exchange, nonperforming loans, agricultural sector.

JEL Classification: G32

REL Classification: $11 \mathrm{C}, 14 \mathrm{~K}$

\section{Introduction}

Agricultural sector registered the highest contribution to the GDP during the analyzed period, underscoring that it has a great capacity to influence the Romanian' economy trend. As it was mentioned by the Romanian scientist Nicholas Georgescu - Roegen, without a sustainable increse, the Earth with not be able to sustain the current level of consumption indefinitely, and this involve consumption indefinitely and needs especially people in rich countries to reduce their current level of physical and energy consumption. (Ipate N, David, G, Ipate I, Bogdan A, 2015). Romanian agriculture sector has a big potential taking into account the following considerations (Ardelean D, 2013):

- the geostrategical position of the region;

- the incresing demand for traditional products;

- goethermal potential;

- multicultural traditions and natural environment. 
Rodean (Cozma) M.D., Baltes N. (2016)

The influence of the macroeconomical variables on the bankruptcy rate of the Romanian Entities working in the agricultural sector

One of the factors with a great probability to influence negatively the agricultural sector was the bankruptcy's rate.

Nowadays, the economy is still recovering after the crisis that begun in 2007, and it exists a lack of trust in the partnership between banks and companies. So banks are interested in those fields that have the smallest bankruptcy's rate. However, during this period banks registered one of the highest non-performing loans rate because of the negative trend of the entire economy (high rates of bankruptcy registered by companies, increasing unemplyment rate and inflation rate, volatile exchange rate etc.). In these conditions, risk management's priority is to diminish the negative consequences of the non-performing loans. So it can be appreciated that it is important to study the vulnerabilities of the agricultural sector and to find out if it can be seen as a risky one.

The study's objectives were:

- To analyze the variables that may have the biggest impact on the agricultural' sector bankruptcy's rate;

- To try to find a trend that this sector may follow in the next period of time;

- To identify the risk that a bank my assume granting new loans to the agricultural companies (high, medium, low).

\section{Literature review}

The alarming increase of the non-performing loans, especially after the crisis began, encouraged many specialists to try to find an explanation for this negative phenomenon.

The evolution of the agricultural sector can be influenced by many factors such as: exchange rate, inflation rate, monetary policy, unemployment rate etc. There were many studies considering that the evolution of the echange rate can influence the agricultural trade, especially the price of aquisitions and the sales.

There are many tools created in order to measure, evaluate and manage credit risk assummed by banks. The most famous ones are Portfolio Manager of Moody's (developed after Merton's Insight), the Risk Metrics Group's CreditMetrics, Wilson Model, Credit Suisse Financial Products' Credit Risk+ (Schmidt, 2012, p $3)$.

It was demonstrated in many studies and stress tests that bank's performance is affected by the following macroeconomic variables: GDP, GDP growth, unemployment, interest rate, inflation, exchange rate, money growth and property prices. In their research Gerlach et al. (2003), Pesola (2001) and Froyland and Larsen (2002) pointed out that macroeconomic developments and financial conditions may affect banking performance. The Pesola' study conclusions indicated that a high indebtedness associated with negative macroeconomic 
Rodean (Cozma) M.D., Baltes N. (2016)

The influence of the macroeconomical variables on the bankruptcy rate of the Romanian Entities working in the agricultural sector

surprises can generate a bank crisis (for a better argumentation into the study it were analyzed the effects of lending boom REPHRASE on bankruptcies and loan losses). From the point of view of Froyland and Larsen, the results of each test may depend on the model used and the assumptions about the baseline scenario (in this way being demonstrated how vulnerable the financial system may be to adverse economic events).

A significant contribution was brought by Michael Boss in 2002, when he created a model regarding the dependence of credit risk (the exposures of non-financial, corporations and individuals were considered) from macroeconomic developments in the macroeconomic sectors of the Austrian economy.

Starting from the basic concept of credit model Merton, the researchers Schuermann and Pesaran in 2003, modeled the function of credit risk in correlation with the borrowers' capital ratios. In turn, these capital ratios were correlated with macroeconomic variables using a similar approach to the Arbitrage Pricing Theory. Koopman and Lucas (2004) used in their model, multivariate and unobserved components in order to separate the credit risk of the business cycle. The decision to use such a model was based on the desire to describe the dynamic behavior of credit risk factors in relation to real economy. The main objective of their study was to determine the impact of the evolution of macroeconomic variables over the loss' distribution of loans portfolios.

The Italian researchers Fiori, Roberta Foglia Antonella Iannotti Simonneta in 2007, in their study attempted to measure the impact that is printed by the economic environment to the evolution of credit risk generated by the exposures of nonfinancial corporations split into eight sectors.

The researcher, Castren was study in 2009, the effects of macroeconomic shocks on VaR for different banks through two steps. Firstly, it was estimated using GVAR model the impact of real GDP, real stock prices, inflation, short-term and long-term interest rates and the euro-dollar exchange rate and secondly the obtained results were included in a regression modeled on the sector specific probability of defaults (PD).

Demonstrated long time ago by the researcher Fridson (1997) between interest rates and default rates there is a negative relationship, especially when the interest rates are increasing, the asset returns are lower.

The legal framework has changed in the last decade, appearing new capital and liquidity standards. So there were many studies trying to analyze, in the context of Basel III Agreement, the cyclical effects in credit risk model. For example Lowe (2002) was intersted in demonstrating if credit risk is low or high in economic booms. In order to achieve its objective in the study it was described how

40 DE GRUYTER OPEN
Studia Universitatis "Vasile Goldis" Arad. Economics Series Vol 26 Issue 2/2016

ISSN: 1584-2339; (online) ISSN: 2285 - 3065.

Web: publicatii.uvvg.ro/index.php/studiaeconomia.Pages $38-47$ 
Rodean (Cozma) M.D., Baltes N. (2016)

The influence of the macroeconomical variables on the bankruptcy rate of the Romanian Entities working in the agricultural sector

macroeconomic considerations is included into credit risk models and risk measurement approach that underlines the New Basel Agreement.

In the study made by Louis Vouldis and Metaxas (2010) on nine first important banks of the Greek banking system, it was analyzed the evolution of nonperforming loans. The results of their studies demonstrated that the evolution of nonperforming loans was mainly due to the quality of management and macroeconomic variables. In the same year, the researcher Kattai, developed a credit risk model for the Estonian banking system. The variables involved in the model were, in particular: nonperforming loans and credit losses registered by the top four Estonian banks. The banks were analyzed separately taking into account the types of granted loans (consumer credit, mortgage and corporate loans). The ratios were modeled considering the evolutions of the macroeconomical framework provided by the following indicators: economical growth, unemployment rate, inflation rate, indebtedness and credit growth.

Such studies were made on the Romanian banking system by Anamaria Benyovszki and Ion Trenca (2011) Tanase Isabela and Moses Altar (2013), Bogdan Chiriacescu and Moses Altar (2010). On the basis of these studies was the methodology developed by Wilson (1997) and integrated into the Credit Portfolio View. Mainly, this proposed methodology links corporate bankruptcy rates and the macroeconomic variables. The study's main objective was to apply a credit risk model that makes a link between macroeconomic variables (such as: growth rate of gross domestic product, unemployment, inflation rate, exchange rate and interest rate, monetary policy) and the default rate of the companies.

\section{Data and methodology}

The research was based on data taken from the sites of the National Institute of Statistics http://statistici.insse.ro and of the Commercial Register www.onrc.ro, being available just between 2010 and 2013 . This was the reason why the research horizon was limited to a period of 4 years. Therefore, in order to homogenize data, the following decision was taken:

1. On-site www.onrc.ro, the data regarding the companies covered in the scope of Law No. 85/2006, classified taking into account their activity, were available only since 2010 .

2. On-site www.insse.ro up to date of research, the related information of 2014 has not been published.

Research was based on annual data. The bankruptcy rate registered by the agricultural sector was determined over the period 2010-2013. The methodology applied in order to determine the default rate was based on the ratio between the number of companies covered by Law number 85/2014 and the total number of 
Rodean (Cozma) M.D., Baltes N. (2016)

The influence of the macroeconomical variables on the bankruptcy rate of the Romanian Entities working in the agricultural sector

companies operating in the agricultural sector in the analyzed period. The sector's selection decision was based on the following arguments: the contribution to GDP and the degree in which the sector was demaged by the macroeconomical conditions after the economic and financial crisis began. The evolution of the bankruptcy rate is shown in the following graph:

Graph 1. The bankruptcy rate of the agricultural sector

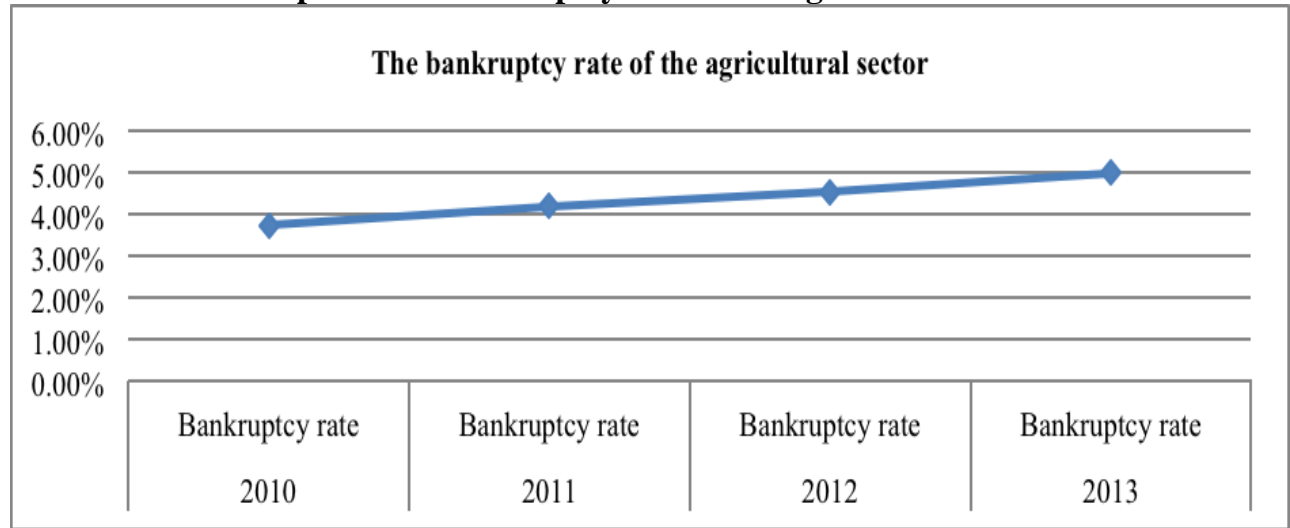

Source: data processed by the authors based on the National Trade Register Office and the National Statistics Institute

The bankruptcy's rate dynamics show an increasing trend of this indicator, even though in the analyzed period, the sector has contributed significantly to the gross domestic product. However, compared to other sectors, the bankruptcy rate registered by the agricultural sector is the lowest.

The macroeconomic variables considered in order to explain the failure rate registered by the agricultural sector were: the gross domestic product (expressed in current prices), inflation rate, exchange rate RON-EURO, the monetary policy interest rate and the unemployment rate.

\section{The interpretation of the results}

The results obtained, after several attempts, demonstrated that the variables that have the greatest capacity to explain the bankruptcy rate are: inflation and the rate of exchange. In these circumstances, the Multilinear regression model generated is the following:

$\mathrm{Rfa}=-\mathbf{1 3 , 7 9 + 4 , 2 1} * \mathrm{Cs}_{\mathbf{i}}-\mathbf{0 , 0 7} * \mathbf{R i}_{\mathrm{i}}++\varepsilon_{\mathrm{i}}$ 
Rodean (Cozma) M.D., Baltes N. (2016)

The influence of the macroeconomical variables on the bankruptcy rate of the Romanian Entities working in the agricultural sector

Where: Rfa - bankruptcy rate of the agriculture sector;

Cs - the rate of exchange RON / EURO, existing at the time i;

$\mathbf{R i}$ - Inflation rate at the time i.

As a first remark of the study, $99.99 \%$ of the variation of the bankruptcy rate registered by the agricultural sector is explained by the exchange rate' movements and inflation. R Square does not significantly differ from the adjusted coefficient of determination ( $\mathrm{R}$ Square), which shows that the regression equation is acceptable (Table 1).

Table 1 - Regression Results Table SUMMARY OUTPUT

\begin{tabular}{lr}
\hline \multicolumn{2}{c}{ Regression Statistics } \\
\hline Multiple R & 0,999998 \\
R Square & 0,999995 \\
Adjusted R Square & 0,999986 \\
Standard Error & 0,001995 \\
Observations & 4 \\
\hline
\end{tabular}

Source: Data processed by the author according to the data published on the websites: ONRC, INSSE and NBR

The picture analysis of variance (ANOVA Table) associated to the estimated regression provides information regarding the significance of the entire regression. The results of the significance test (Significance F) demonstrate the rejection of a null hypothesis, according to which the regression coefficients are not null. (Significance $\mathrm{F}<\alpha$, demonstrates the acception of the alternative hypothesis).

Table 2 - The ANOVA table

ANOVA

\begin{tabular}{lrrrrr}
\hline & $D f$ & \multicolumn{1}{c}{$S S$} & \multicolumn{1}{c}{$M S$} & $F$ & \multicolumn{2}{c}{ Significance $F$} \\
\hline Regressio & & 0,85159 & 0,42579 & 107020, & \\
$\mathrm{n}$ & 2 & 6 & 8 & 6 & 0,002161 \\
& & $3,98 \mathrm{E}-$ & $3,98 \mathrm{E}-$ & & \\
Residual & 1 & 06 & 06 & & \\
Total & 3 & 0,8516 & & & \\
\hline
\end{tabular}

Source: Data processed by the author according to the data published on the websites: ONRC, INSSE and NBR

The third table follows the estimated values for the model coefficients and also the statistics needed to verify usual assumptions over coefficients. Given that the 
Rodean (Cozma) M.D., Baltes N. (2016)

The influence of the macroeconomical variables on the bankruptcy rate of the Romanian Entities working in the agricultural sector

obtained values for the coefficients are significantly different from 0 , the null hypothesis is rejected. Considering the chosen materiality $\alpha=0.05$, it rejects the null hypothesis in case of all terms of the regression: free term, inflation rate and the exchange rate. In the estimated regression model, coefficients can take the following values:

$$
\begin{aligned}
14,770 & <\alpha_{0}<12809 \\
3991 & <C_{s}<4428 \\
-0.073 & <R_{i}<-0.058 .
\end{aligned}
$$

Table 3 - Estimated values for model coefficients

\begin{tabular}{lllllll}
\hline & Coefficients & $\begin{array}{l}\text { Standard } \\
\text { Error }\end{array}$ & t Stat & P-value & $\begin{array}{l}\text { Lower } \\
95 \%\end{array}$ & $\begin{array}{l}\text { Upper } \\
95 \%\end{array}$ \\
\hline $\begin{array}{l}\text { Intercept } \\
\text { Rate of exchange }\end{array}$ & $-13,789$ & 0,077 & $-178,681$ & 0,004 & $-14,770$ & $-12,809$ \\
$\begin{array}{l}\text { RON / EURO } \\
\text { Inflation Rate }\end{array}$ & 4,210 & 0,017 & 244,643 & 0,003 & 3,991 & 4,428 \\
(IPC) & $-0,065$ & 0,001 & $-111,943$ & 0,006 & $-0,073$ & $-0,058$ \\
\hline
\end{tabular}

Source: Data processed by the author according to the data published on the websites: ONRC, INSSE and NBR

The estimated value of exchange rate 4.21 shows that a $1 \%$ increase in exchange rate will generate a growth of $4.21 \%$ in the rate of bankruptcy of the agricultural sector.

The independence of the variables that are introduced in the model is underlined by the obtained correlation between them, and by $r$ values that are par (table no 4 ).

Table 4 - Matrix correlation $r$

\begin{tabular}{llll}
\hline & $\begin{array}{l}\text { Bankruptcy rate } \\
\text { registered in the } \\
\text { agricultural sector }\end{array}$ & $\begin{array}{l}\text { Rate of } \\
\text { exchange } \\
\text { RON/EURO }\end{array}$ & $\begin{array}{l}\text { Inflation } \\
\text { Rate (IPC) }\end{array}$ \\
\hline $\begin{array}{l}\text { Bankruptcy rate registered in the } \\
\text { agricultural sector }\end{array}$ & 1 & & \\
$\begin{array}{l}\text { Rate of exchange RON/EURO } \\
\text { Inflation Rate (IPC) }\end{array}$ & 0,970283544 & 1 & \\
\hline
\end{tabular}

Source: Data processed by the author according to the data published on the websites: ONRC, INSSE and NBR

The residuals analysis plays an important role in the multilinear regression model validation. The fact that the values are positioned horizontally (as shown in the diagrams below) confirms the assumptions of normality.

\section{DE GRUYTER} OPEN
Studia Universitatis "Vasile Goldis" Arad. Economics Series Vol 26 Issue 2/2016

ISSN: 1584-2339; (online) ISSN: 2285 - 3065.

Web: publicatii.uvvg.ro/index.php/studiaeconomia.Pages $38-47$ 
Rodean (Cozma) M.D., Baltes N. (2016)

The influence of the macroeconomical variables on the bankruptcy rate of the Romanian Entities working in the agricultural sector

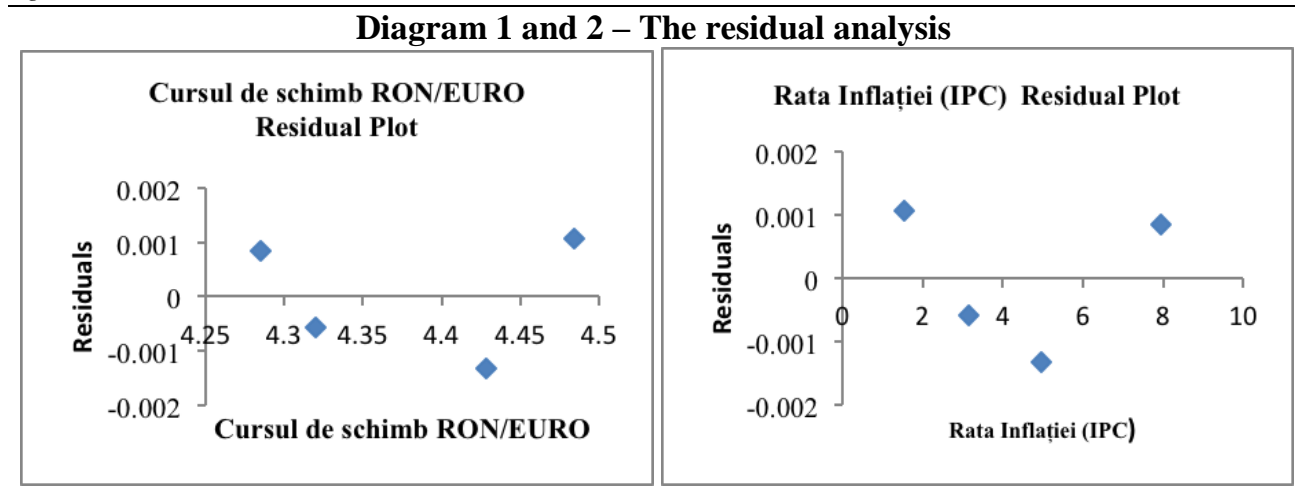

Source: Data processed by the author according to the data published on the websites: ONRC, INSSE and NBR

The quality pattern is demonstrated by the situation of normality, and also by the linear trend as is shown in diagrams "FIT PLOT".

\section{Diagram 3, 4 and 5 - The residual analysis}
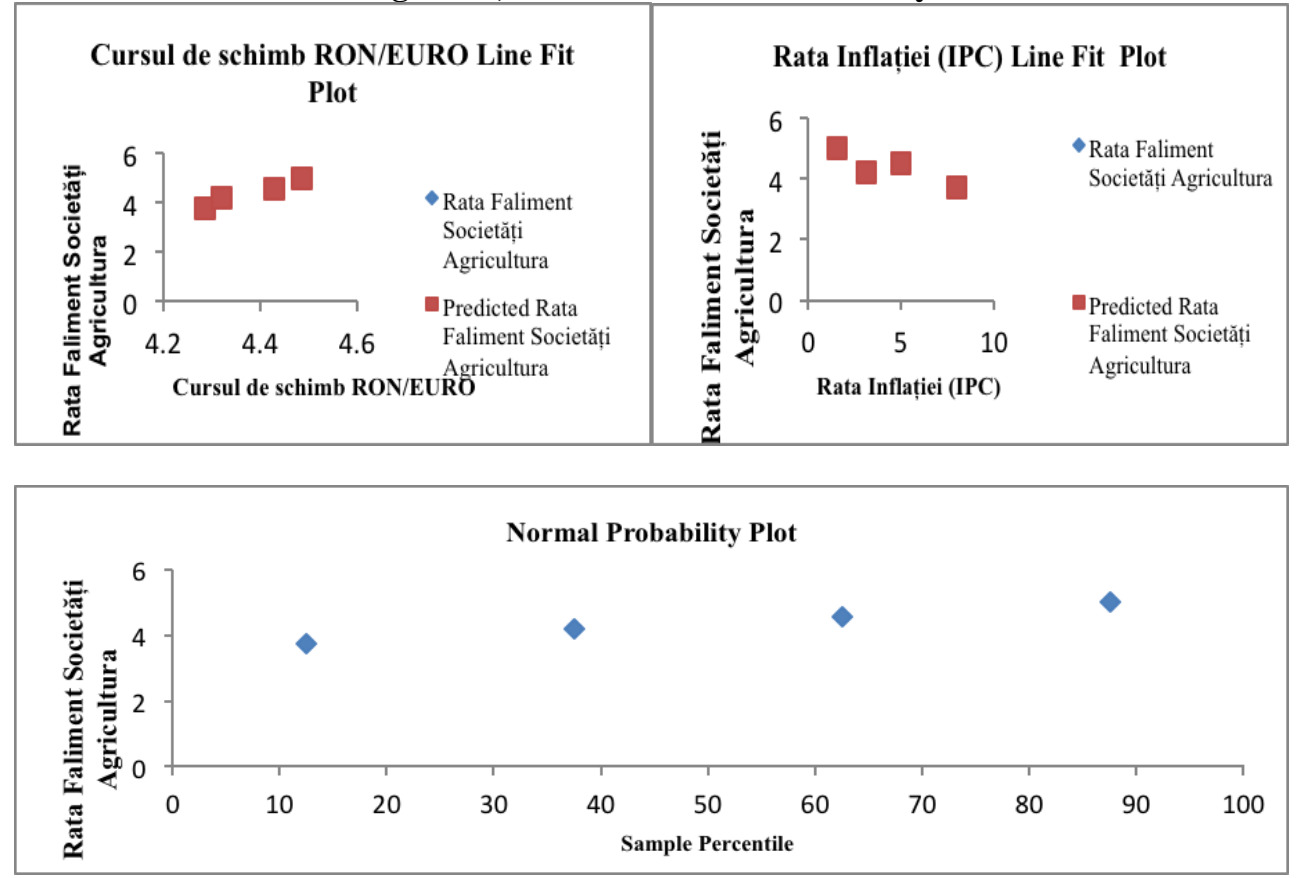

Source: Data processed by the author according to the data published on the websites: ONRC, INSSE and NBR 
The obtained results demonstrate the viability of the model as such. The bankruptcy rate recorded in the agricultural sector is significantly influenced by the evolution of the exchange rate and inflation. This idea can be explained by the fact that both macroeconomic variables put pressure on the industry' price level, which in the non-financial companies can be turned into a negative or positive element for increasing / decreasing profitability.

\section{Conclusions and future guidelines}

From the point of view of the creditors, especially for commercial banks, increasing bankruptcy rates suggest a growth of the credit risk in case of additional exposures. In this context, knowing that those factors are likely to influence the evolution of this rate, it could prove to be a very useful tool for risk managers. The regression model validation in this study demonstrate that for the agricultural sector, the exchange rate and inflation are two variables likely to influence its development. As such, given that over the explained macroeconomical variables a major influence has the monetary policy performed by the National Bank of Romania, it can be said that the bank's decision to lower monetary policy rates helped to stabilize the sector.

A future research, can be focused on a comparative study between the default rate registered by the agricultural sector and by other sectors of the economy. Such study is designed to identify the most risky sector for bank lending perspective and it can be able to explain the NPL ratio recorded in recent years by commercial banks operating in the Romanian banking system.

\section{Bibliography}

1. Ardelean D, (2013), Projects portofolio for ecological reconstruction of the Ier Valley and their funding, Studia Universitatis "Vasile Goldis" Arad -Economics Series Vol 23 Issue $4 / 2013$

2. Boss, M., A Macroeconomic Credit Risk Model for Stress Testing the Austrian Credit Portfolio, in: Financial Stability Report 4. OeNB. http://www.oenb.at/en/ img/fsr_04_tcm16-8061.pdf

3. Castren, O., Fitzpatrick, T. and Sydow, M. (2009), Assessing Portfolio Credit Risk Changes in a Sample of EU Large and Complex Banking Groups in Reaction to Macroeconomic Shocks, ECB Working Paper Series no 1002 / February.

4. Fiori, R., Foglia, A., Iannotti, S. (2007), Estimating Macroeconomic Credit Risk and Sectoral Default Rate Correlations for the Italian Economy, 2nd Expert Forum on Advanced Techniques on Stress Testing, International Monetary Fund and De Nederlandsche Bank, Amsterdam, The Netherlands, October 23-24

46 DE GRUYTER OPEN
Studia Universitatis "Vasile Goldis" Arad. Economics Series Vol 26 Issue 2/2016 ISSN: 1584-2339; (online) ISSN: 2285 - 3065.

Web: publicatii.uvvg.ro/index.php/studiaeconomia.Pages $38-47$ 
Rodean (Cozma) M.D., Baltes N. (2016)

The influence of the macroeconomical variables on the bankruptcy rate of the Romanian Entities working in the agricultural sector

5. Fridson, M., C. Garman, and S. Wu, (1997), Real interest rates and the default rates on high-yield bonds, Journal of Fixed Income, September, 27-34.

6. E. Frøyland and K. Larsen (2002), How vulnerable are financial institutions to macroeconomic changes? An analysis based on stress testing, Economic Bulletin, Norges Bank, October, 2002

7. Ipate, N., David, G., Ipate, I., Bogdan, A. (2015), The bioeconomy model in future sustainable development, Studia Universitatis "Vasile Goldis" Arad -Economics Series DOI: 10.1515/sues-2015-0016

8. Kattai, R. (2010), Credit risk model for the Estonian Banking Sector, Bank of Estonia Working Papers, 1/2010

9. Koopamn S, Lucas A (2005), Business and Default Cycles for Credit Risk, Journal of Applied Econometrics, 20:311-323.

10. Lowe P (2002), Credit risk measurement and procyclicality, BIS Working Papers, September.

11. Pesaran M, Schuermann T (2003), Credit Risk and Macroeconomic Dynamics, Federal Reserve Bank of New York, March 2003

12. Pesola J. (2001), The role of macroeconomic shocks in banking crises. Unpublished Working Paper, Bank of Finland, 2001

13. Schuh, G. Edward (1974), The Exchange Rate and U.S. Agriculture, American Journal of Agricultural Economics. 56:1 (February). pp. 1-13.

14. Schmidt Bernd, (2012), Credit Risk Pricing Models: Theory and Practice, Springer

15. Vasquez F, Tabak B., Souto M, (2010), A Macro Stress Test Model of Credit Risk for the Brazilian Banking Sector, Working Series 226, Bank of Brazil.

16. Virolainen, K. (2004), Macro Stress Testing with a Macroeconomic Credit Risk Model for Finland, Bank of Finland, Discussion Papers, No.18.

17. Legea numarul 85/2014 privind procedurile de prevenire a insolventei si de insolventa

18. www.onrc.ro

19. http://statistici.insse.ro 